\title{
PENGARUH PERLAKUAN PELARUTAN TERHADAP SIFAT MEKANIK DAN STRUKTUR MIKRO PADUAN TERNER Zr-Nb-Mo UNTUK BIOMATERIAL
}

\section{EFFECT OF SOLUTION TREATMENT ON MECHANICAL PROPERTIES AND MICRO STRUCTURE TERNARY ALLOY Zr-Nb FOR BIOMATERIAL}

\author{
Dzikry Syamsul Nur Alam a , Pradoto Ambardi ${ }^{b}$, Djoko Hadi Prajitno ${ }^{c}$ \\ a,b Teknik Metalurgi, Universitas Jenderal Achmad Yani, Bandung, Indonesia. \\ c PSTNT-BATAN, JI. Tamansari 71 Bandung 40132, Indonesia. \\ e-mail : dzikrysyamsulnuralam@gmail.com,
}

\begin{abstract}
Abstrak
Penelitian dilakukan untuk mempelajari pengaruh perlakuan pelarutan terhadap sifat mekanik dan stuktur mikro paduan terner Zr-Nb-Mo untuk biomaterial. Paduan zirkonium dapat digunakan sebagai bahan implan. Paduan $\mathrm{Zr}-5 \mathrm{Nb}-\mathrm{xMo}(\mathrm{x}=0,1,3$ dan $5 \% \mathrm{wt})$ dilakukan perlakuan pelarutan dengan variasi temperatur $900^{\circ} \mathrm{C}, 950^{\circ} \mathrm{C}$ dan $1000^{\circ} \mathrm{C}$ dengan pendinginan cepat menggunakan medium air. Hasilnya menunjukan bahwa peningkatan kandungan molibdenum, dapat meningkatkan fasa $\beta$ $\mathrm{Zr}$ dan peningkatan temperatur perlakuan pelarutan dapat meningkatkan kekerasan paduan zirconium. Hal tersebut terjadi karena unsur molibdenum bertindak sebagai beta stabilizer dan perlakuan pelarutan membentuk perubahan bentuk fasa $\beta-\mathrm{Zr}$ dari plate menjadi lath yang lebih halus. Pengujian kekerasan Rockwell $C$ dengan nilai kekerasan tertinggi $53,67 \mathrm{HRC}$ paduan $\mathrm{Zr}-5 \mathrm{Nb}-1 \mathrm{Mo}$ perlakuan pelarutan $1000^{\circ} \mathrm{C}$, fasa yang terbentuk adalah $\alpha-Z r, \beta-Z r$, dan intermetalik $\mathrm{Mo}_{2} \mathrm{Zr}$ paduan $\mathrm{Zr}$ $5 \mathrm{Nb}$-5Mo yang diidentifikasi menggunakan $X$-Ray Diffraction (XRD).
\end{abstract}

Kata kunci : Paduan Zr-5Nb-xMo, perlakuan pelarutan, beta stabilizer.

\begin{abstract}
The research was to investigate the effect of solution treatment on mechanical properties and micro structure of ternary alloy $\mathrm{Zr}-\mathrm{Nb}-\mathrm{Mo}$ for biomaterial. Zirconium alloy can be used as an implant material. The temperature variation of solution treatment alloy $\mathrm{Zr}-5 \mathrm{Nb}-\mathrm{xMo}(x=0,1,3$ dan $5 \% w t$ ) is $900^{\circ} \mathrm{C}, 950^{\circ} \mathrm{C}$ and $1000^{\circ} \mathrm{C}$ with water quenching. The result shows that the phase $\beta-Z r$ will increase by increasing the consentration of molybdenum and rise up the temperature solution treatment can for hardening the zirconium alloy. These happens because molybdenum serves as a beta stabilizer and the solution treatment generates the tansformation of phase $\beta$-Zr from plate into a finer lath. The hardness testing using Rockwell $C$ with the highest hardness value 53.67 HRC Zr$5 \mathrm{Nb}-1 \mathrm{Mo}$ alloy solution treatment $1000^{\circ} \mathrm{C}$, The formed phases are $\alpha-Z r$, $\beta$-Zr, and intermetalic $\mathrm{Mo}_{2} Z r \mathrm{Zr}-5 \mathrm{Nb}-5 \mathrm{Mo}$ alloy yang identified by using $X$ Ray Diffraction (XRD).
\end{abstract}

Key Words: Zr-5Nb-xMo alloys, solution treatment, beta stabilizer

Diterima (received ) : 18 September 2018 , Direvisi (revised ) : 04 Maret 2019 , Disetujui (accepted) : 11 Maret 2019 


\section{PENDAHULUAN}

Material logam saat ini sangat bermanfaat bagi kemajuan medis terutama pada biomaterial yang berfungsi sebagai implan pengganti jaringan tubuh manusia. Sekitar $70-80 \%$ implan terbuat dari biomaterial logam ${ }^{1)}$.

Penyembuhan cedera patah tulang dapat ditangani dengan pemasangan implan pada tulang orthopaedic implant dan material yang sering digunakan sebagai implan ortopedi adalah logam ${ }^{2}$. Prinsip penggunaan biomaterial logam sebagai bahan baku implan ortopedi didasarkan pada karakteristik kompatibilitas biomekanik, biokimia, dan kompatibilitas biologi yang cukup baik terhadap tubuh. Beberapa biomaterial logam yang sering digunakan sebagai material implan adalah SUS 316L stainless steel, paduan $\mathrm{Co}-\mathrm{Cr}$, dan paduan titanium ${ }^{3}$. Material yang mulai dikembangkan sebagai material implan adalah zirkonium. Bukti in vivo menunjukkan bahwa implan zirkonium menunjukkan osseointegrasi yang baik dan bahkan tingkat yang lebih tinggi dari implan titanium ${ }^{4)}$.

Logam berbasis $\mathrm{Zr}$ dipilih sebagai aplikasi biomaterial dikarenakan nilai kerentanan magnet yang terkecil dibandingkan jenis-jenis logam yang umum digunakan untuk aplikasi biomaterial dibidang medis. Selain itu, $\mathrm{Zr}$ memiliki ketahanan korosi yang baik karena permukaan $\mathrm{Zr}$ dapat membentuk lapisan pasif ${ }^{1)}$. Zr juga memiliki sifat sitoksitas rendah $^{5}$, yang artinya tidak mengganggu jaringan tubuh dengan tidak menyebabkan alergi. Namun, jika $\mathrm{Zr}$ tidak dipadukan dengan unsur lain, maka sifat mekanis yang dihasilkan akan lebih rendah dibandingkan titanium dengan paduannya. Sehingga dilakukan penambahan unsur $\mathrm{Nb}$ dan Mo, yang berfungsi sebagai unsur penguat sistem mekanis ${ }^{6}$. Selain itu, $\mathrm{Nb}$ dan Mo juga memiliki sifat sitotoksitas yang rendah dan kerentanan magnetik yang rendah $^{5}$, sehingga dapat mendukung sebagai paduan untuk material zirkonium.Paduan $\mathrm{Zr}-\mathrm{Nb}$ memiliki ketahanan korosi, tahan lama, dan biokompatibel untuk komponen ortopedi yang terutama ditujukan sebagai implan pinggul dan lutut ${ }^{7)}$. Proses perlakuan pelarutan dilakukan pada paduan $\mathrm{Zr}$-Nb-Mo dapat mempengaruhi ketahanan korosi, sifat mekanis dan ukuran butirnya, transformasi martensit dapat terjadi pada paduan $\mathrm{Zr}$ yang didinginkan dengan cepat dari temperatur tinggi fasa hcp menjadi bcc martensit, umumnya ada dua jenis yaitu lath martensite dan plate martensite ${ }^{8)}$.
Berdasarkan latar belakang tersebut penelitian ini dilakukan untuk mengetahui pengaruh penambahan unsur niobium pada paduan $\mathrm{Zr}-5 \mathrm{Nb}-\mathrm{xM}$ o dimana variasi Mo $(0 \%$, $1 \%$, $3 \%$, dan $5 \%$ ) ( $\%$ massa) dan pengaruh dilakukan proses perlakuan pelarutan quenching menggunakan medium air untuk meningkatkan sifat mekanis serta ketahanan korosi berdasarkan morfologi struktur mikro yang terbentuk sebagai aplikasi biomaterial.

\section{BAHAN DAN METODE}

Bahan baku yang digunakan berupa logam zirconium sponge 99,99\%, niobiumwire komposisi $99,98 \%$ dan molybdenum rounded $99,98 \%$ ditimbang dengan berat total 15 gram setiap sampel.

Tahapan proses tersebut meliputi, peleburan paduan $\mathrm{Zr}-5 \mathrm{Nb}-\mathrm{xMo}(\mathrm{x}: 0,1,3$, $5 \% \mathrm{wt}$ ) hasil penimbangan menggunakan arc melting furnace. Peleburan dilakukan sebanyak empat kali dan dibuat berbentuk oval seperti pada gambar 1 .

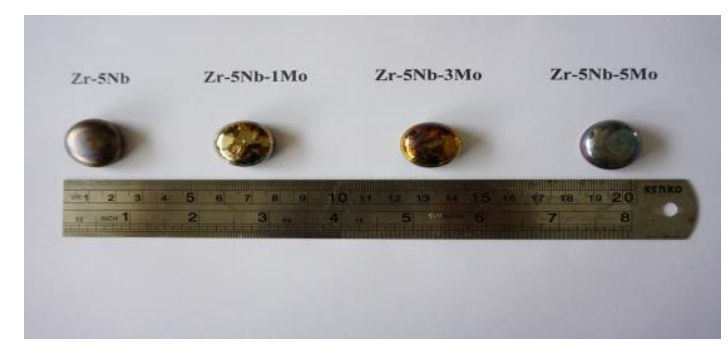

Gambar 1.

Spesimen Hasil Peleburan

Spesimen hasil peleburan dipotong menjadi empat bagian untuk dilakukan proses solution treatment pada temperatur $900^{\circ} \mathrm{C}, 950^{\circ} \mathrm{C}$, dan $1000^{\circ} \mathrm{C}$ menggunakan alat tube furnace dengan gas argon agar tidak terjadi oksidasi dan pendinginan cepat menggunakan media air. Proses solution treatment dapat dilihat pada gambar skematik seperti pada Gambar 2.

TEMPERATUR $\left({ }^{\circ} \mathrm{C}\right)$

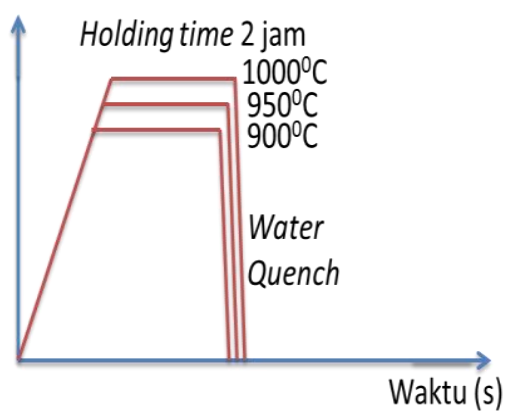

Gambar 2.

Skematik Solution Treatment 


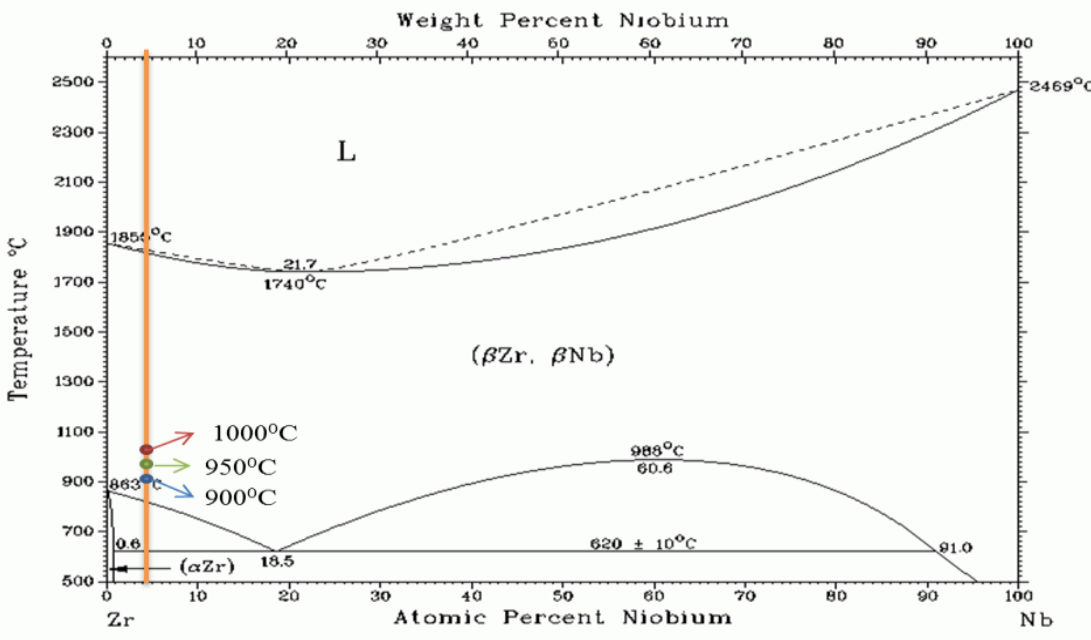

Gambar 3.

Diagram Biner $\mathrm{Zr}-\mathrm{Nb}^{9}$

Karakterisasi sampel yang dilakukan meliputi, pengujian komposisi sampel dengan PMI (Positive Material Identification), pengujian metalografi mengunakan mikroskop optik dengan 2 gram ammonium biflouride, $50 \mathrm{~mL}$ etanol dan $100 \mathrm{~mL}$ air secara imersi dengan waktu 10-15 menit, pengujian kekerasan menggunakan Rockwell skala C, pengujian komposisi fasa $\beta-Z r$ dengan aplikasi image $\mathrm{J}$ dan pengujian $X R D$ (X-Ray Diffraction) untuk mengetahui jenis fasa pada paduan.

HASIL DAN PEMBAHASAN

Pengujian komposisi kimia
Hasil pengujian komposisi kimia dengan $P M I$ ditunjukkan oleh Tabel 1.

Tabel 1.

Data Analisis Komposisi PMI

\begin{tabular}{ccccc}
\hline Spesimen & $\mathrm{Zr}(\%)$ & $\mathrm{Nb}(\%)$ & $\mathrm{Mo}(\%)$ & Total (\%) \\
\hline Zr-5Nb & 93,973 & 5,977 & - & 99,95 \\
Zr-5Nb-1Mo & 93,549 & 5,720 & 0,716 & 99,985 \\
Zr-5Nb-3Mo & 91,753 & 5,174 & 3,029 & 99,956 \\
Zr-5Nb-5Mo & 89,207 & 5,684 & 5,082 & 99,973 \\
\hline
\end{tabular}

Komposisi hasil pengujian dikonversi menjadi \%mol kemudian diplot pada diagram terner Zr-Nb-Mo temperatur 310K.

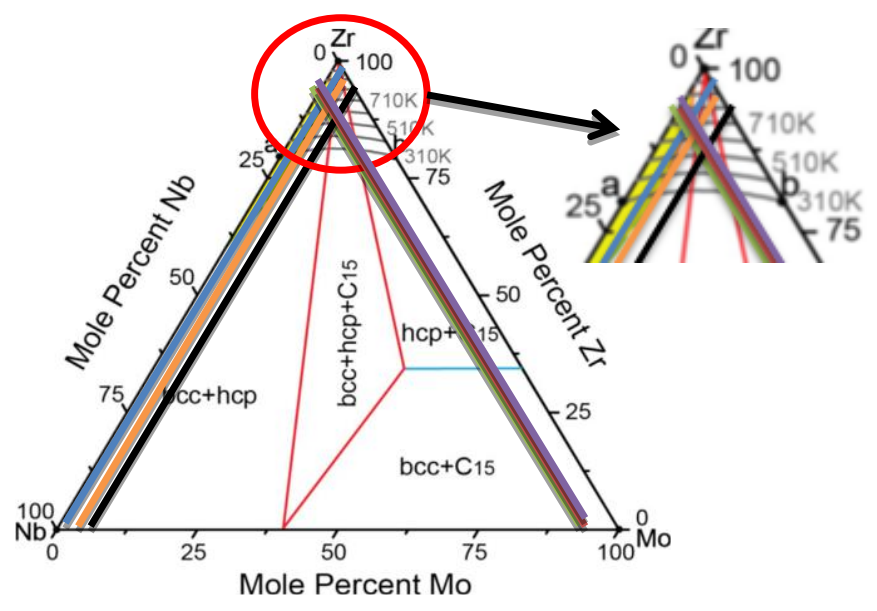

Gambar 4.

Diagram Terner Zr-Nb-Mo 310K ${ }^{9}$.

Pada diagram terner seperti Gambar 4., daerah hcp merupakan fasa $\alpha-Z r$, bcc merupakan $\beta-\mathrm{Zr}$ dan $\mathrm{C}_{15}$ merupakan senyawa $\mathrm{Mo}_{2} \mathrm{Zr}^{9}$. Hasil plot pada diagram terner terlihat bahwa paduan $\mathrm{Zr}-5 \mathrm{Nb}-1 \mathrm{Mo}$ serta $\mathrm{Zr}-5 \mathrm{Nb}-3 \mathrm{Mo}$ memiliki fasa $\alpha-\mathrm{Zr}$ dan $\beta$ - 
$\mathrm{Zr}$, sedangkan paduan $\mathrm{Zr}-5 \mathrm{Nb}-5 \mathrm{Mo}$ memiliki fasa $\alpha-Z r, \beta-Z r$ dan senyawa intermetalic $\mathrm{Mo}_{2} \mathrm{Zr}$

\section{Pengujian Metalografi Kualitatif}

Pengujian metalografi kualitatif dilakukan untuk melihat bentuk struktur mikro sampel penelitian beserta jenis fasa yang terbentuk pada sampel. Hasil pengujian metalografi ditunjukkan oleh Gambar 5. sebagai berikut:

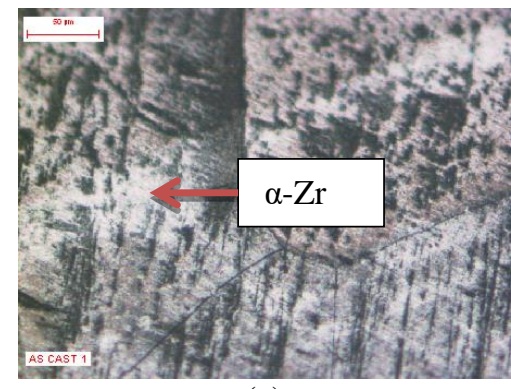

(a)

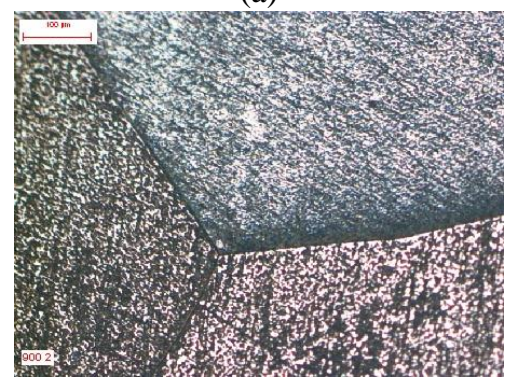

(b)

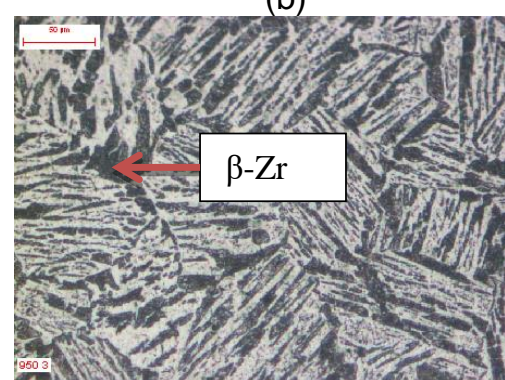

(c)

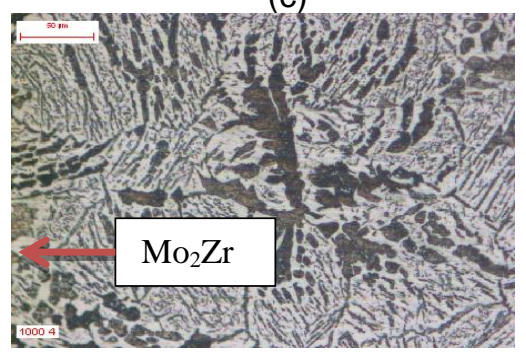

(d)

Gambar 5.

Struktur Mikro Spesimen Pembesaran $200 \mathrm{x}$

Paduan Zr-5Nb (as-cast) (a), paduan $\mathrm{Zr}$ $5 \mathrm{Nb}-1 \mathrm{Mo}$ solution treatment $900^{\circ} \mathrm{C}$ (b), paduan $\mathrm{Zr}-5 \mathrm{Nb}-3 \mathrm{Mo}$ solution treatment $950^{\circ} \mathrm{C}$ (c) dan paduan $\mathrm{Zr}-5 \mathrm{Nb}-5 \mathrm{Mo}$ solution treatment $1000^{\circ} \mathrm{C}(\mathrm{d})$.
Hasil metalografi kualitatif terlihat bahwa yang berwana hitam merupakan fasa $\beta-Z r$, warna putih fasa $\alpha-Z r$, dan warna antara hitam dan putih diantara fasa $\beta-Z r$ adalah senyawa intermetalik $\mathrm{Mo}_{2} \mathrm{Zr}^{10}$.

Adanya Mo juga dapat menstabilkan fasa- $\beta$ pada sistem biner paduan $\mathrm{Zr}$-Mo, terutama ketika kadar Mo di atas $3 \%{ }^{11)}$, dan dengan perlakuan pelarutan maka fasa $\beta-Z r$ berubah bentuk menjadi lath martensite $\beta$ $Z r^{4}$. Fasa $\alpha-Z r$ menjadi lebih halus tersebar pada butir fasa $\beta-Z r$ seiring peningkatan temperatur solution treatment. Senyawa intermetalic $\mathrm{Mo}_{2} \mathrm{Zr}$ hanya terbentuk pada paduan $\mathrm{Zr}-5 \mathrm{Nb}-5 \mathrm{Mo}$.

\section{Pengujian Metalografi Kuantitatif}

Pengujian ini dilakukan dengan
mengolah gambar struktur mikro menggunakan aplikasi image $\mathrm{J}$. sehingga di dapatkan data grafik persentase fasa $\beta-Z r$ sebagai berikut:

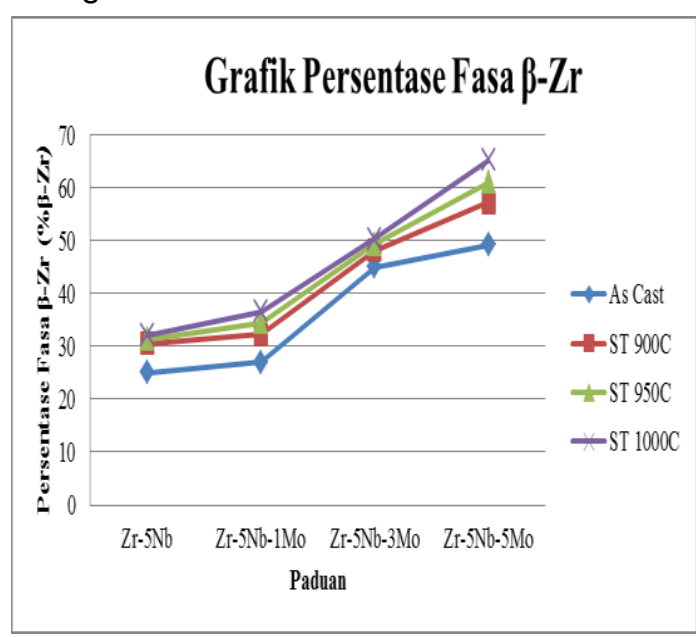

Gambar 6

Grafik Persentase Fasa $\beta-Z r$

Hasil pengujian pada Gambar 6 . menunjukan paduan biner $\mathrm{Zr}-5 \mathrm{Nb}$ memiliki persentase fasa $\beta-Z r$ sebesar $25,05 \%$, hal ini terjadi karena $\mathrm{Nb}$ bersifat beta stabilizer6), dengan bertambahnya paduan Mo terjadi peningkatan fasa $\beta-Z r$ terutama pada penambahan Mo $3 \%$ wt fasa beta yang dihasilkan 45,05\%, meningkat pesat jika dibandingkan dengan Mo $1 \%$ wt sebesar 26,96\%. Peningkatan ini membuktikan bahwa Mo dapat menjadi beta stabilizer pada penambahan $3 \% w^{111}$. Peningkatan fasa $\beta-Z r$ berbanding lurus dengan meningkatnya temperatur solution treatment, terlihat pada paduan $\mathrm{Zr}-5 \mathrm{Nb}-5 \mathrm{Mo}$ dengan temperatur $1000^{\circ} \mathrm{C}$ menghasilkan fasa $\beta-\mathrm{Zr}$ $65,25 \%$. 


\section{Pengujian Kekerasan}

Pengujian dilakukan menggunakan Rockwell skala $\mathrm{C}$ hasil rata-ratanya ditunjukkan oleh Tabel 2. sebagai berikut:

Tabel 2.

Data Kekerasan Spesimen

\begin{tabular}{lcccc}
\hline \multirow{2}{*}{ Paduan } & \multicolumn{4}{c}{ Hardness Rockwell $C($ HRC) rata-rata } \\
& As Cast & ST $900^{\circ} \mathrm{C}$ & ST $950^{\circ} \mathrm{C}$ & ST $1000^{\circ} \mathrm{C}$ \\
\hline Zr-5Nb & 45,67 & 48 & 48,83 & 50,5 \\
Zr-5Nb-1Mo & 49,33 & 50 & 51 & 53,67 \\
Zr-5Nb-3Mo & 48,33 & 48.5 & 50,17 & 50,83 \\
Zr-5Nb-5Mo & 48,0 & 48.33 & 50 & 51 \\
\hline
\end{tabular}

Data pengujian kekerasan dibuat menjadi grafik nilai kekerasan spesimen seperti yang ditunjukkan pada Gambar 7.

Gambar 7. menunjukan bahwa dari paduan biner $\mathrm{Zr}-5 \mathrm{Nb}$ (as cast) menuju paduan Zr-5Nb-1Mo (as cast) terjadi peningkatan kekerasan menjadi 49,33 HRC yang diakibatkan dari pengaruh penguatan larutan padat dari $1 \%$ wt Mo, pada penambahan Mo sebesar 3\%wt terjadi penurunan kekerasan karena peningkatan fasa $\beta-Z r$, fasa $\beta-Z r$ memiliki kekerasan yang lebih rendah dari fasa $\alpha-Z r^{4}$, paduan $\mathrm{Zr}-5 \mathrm{~N}$ $5 \mathrm{Mo}$ (as cast) tidak terjadi penurunan yang signifikan meskipun fasa $\beta-Z r$ semakin banyak karena membentuk fasa intermetalik $\mathrm{Mo}_{2} Z r$ di dalam matriks $\alpha-Z r^{12}$. Pada hasil proses solution treatment terjadi peningkatan kekerasan yang diakibatkan dari terbentuknya lath martenstie $\beta-Z r^{4,13)}$. Peningkatan temperatur pemanasan dapat meningkatkan kekerasan karena fasa $\alpha-Z r$ semakin halus dan tersebar pada butir fasa $\beta-\mathrm{Zr}$ dengan meningkatnya temperatur pemanasan

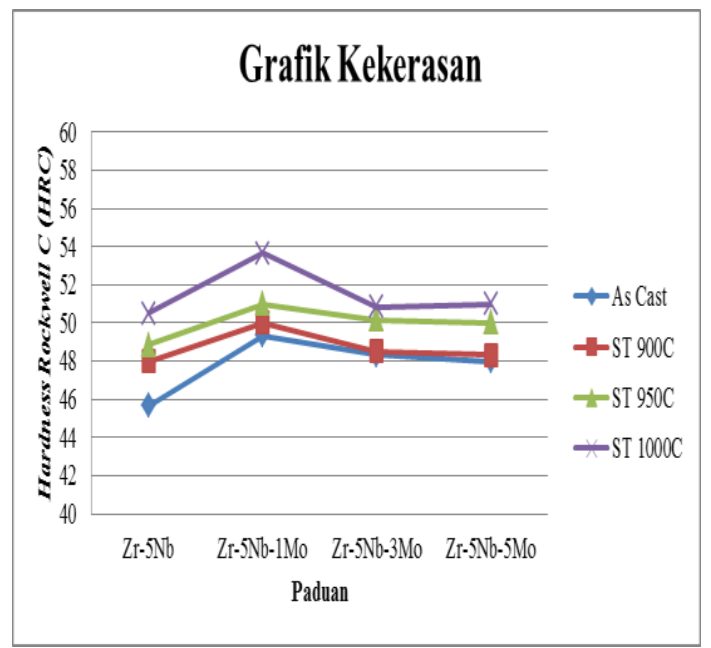

Gambar 7

Grafik Kekerasan Spesimen

\section{Pengujian XRD (X-Ray Diffraction)}

Pengujian XRD menghasilkan grafik seperti pada Gambar 8. berikut ini.

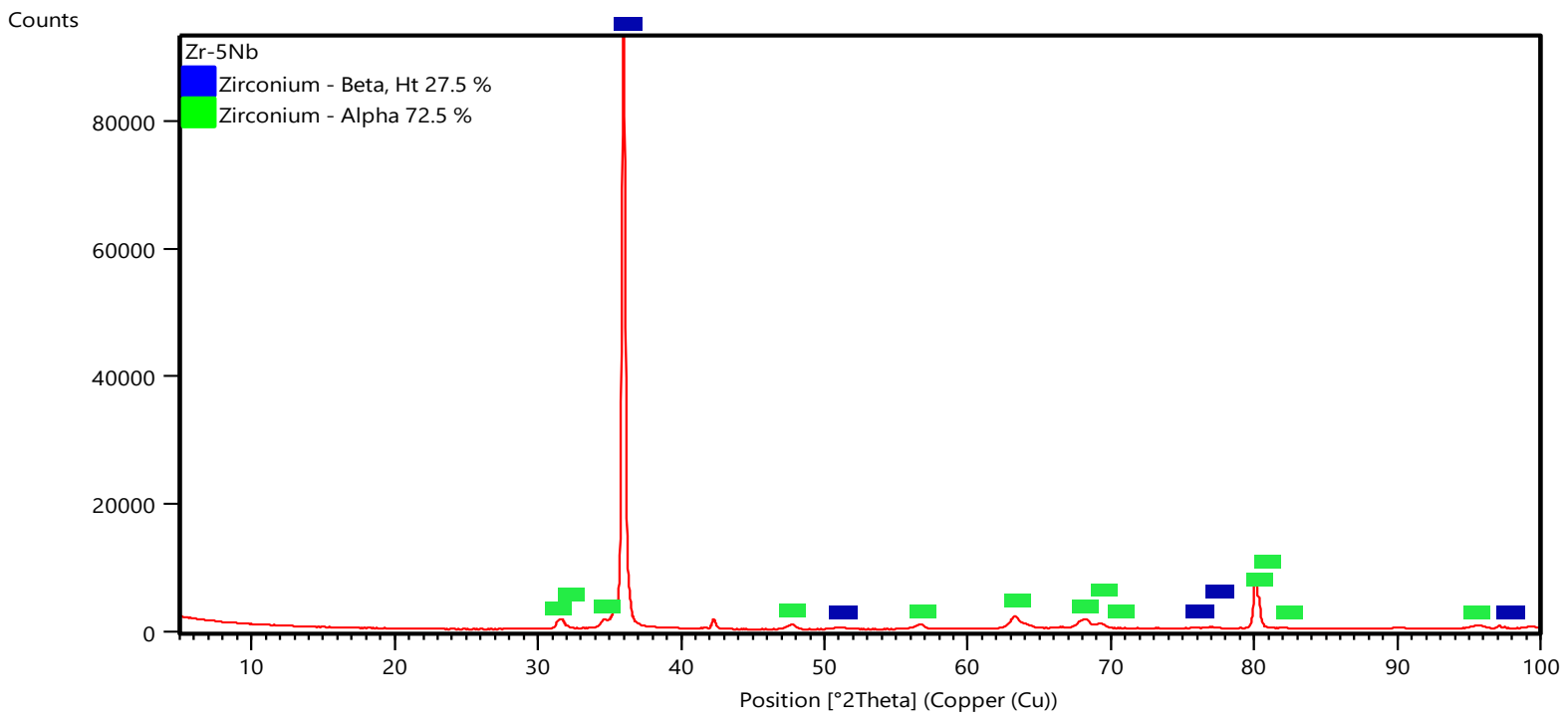

(a) 


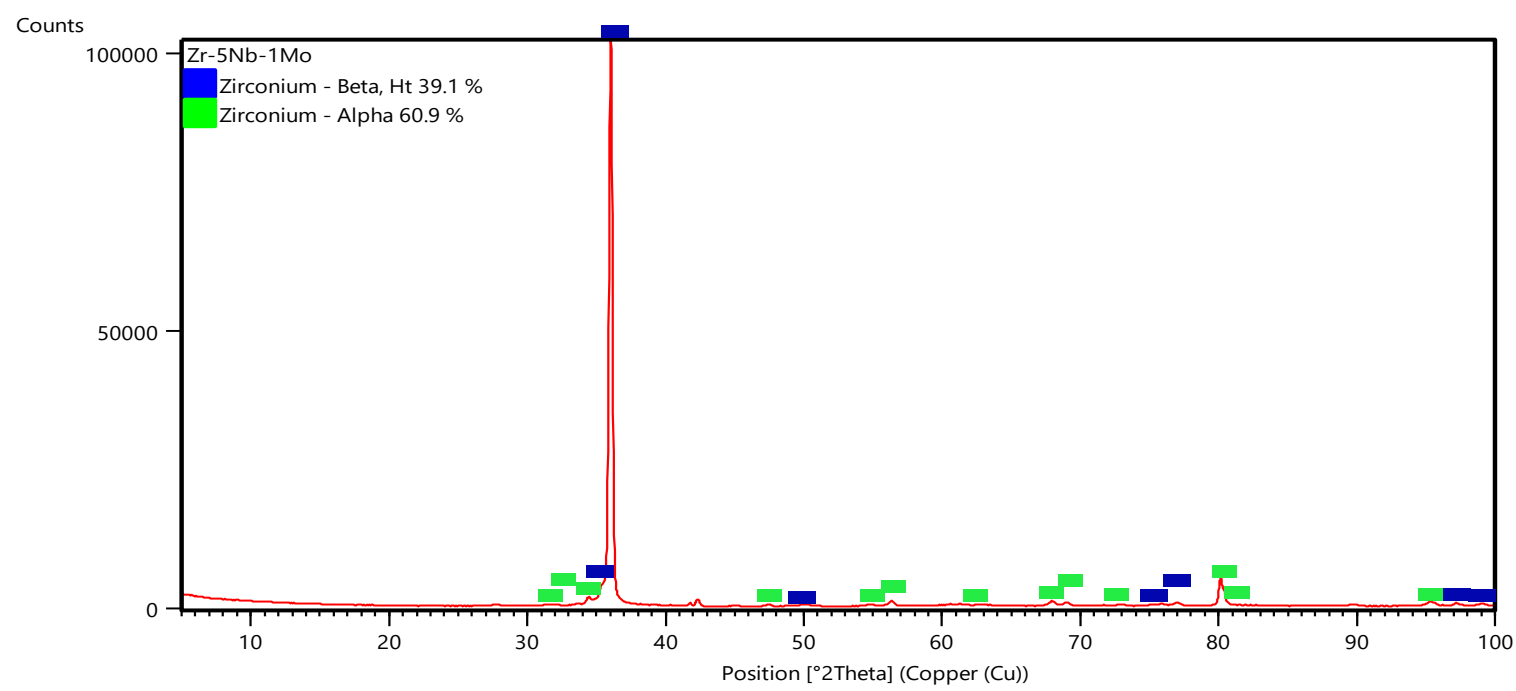

(b)

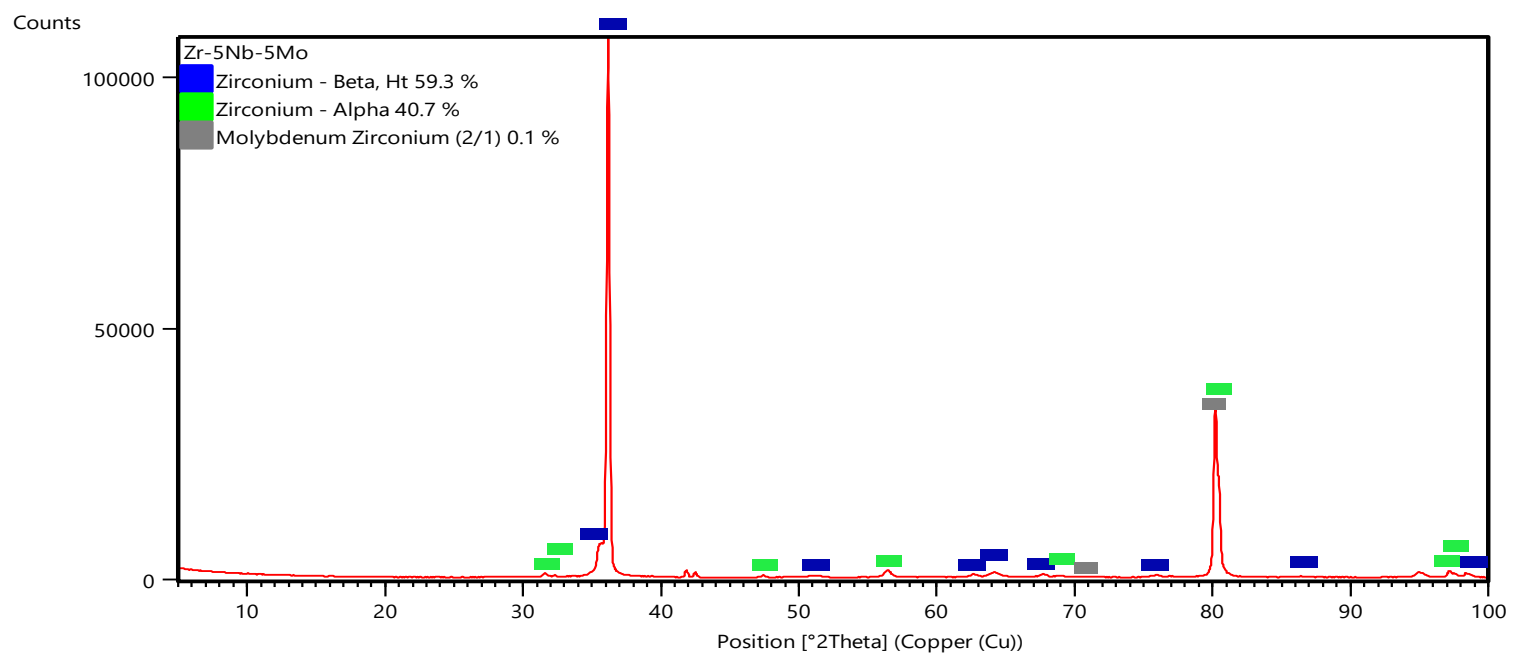

(c)

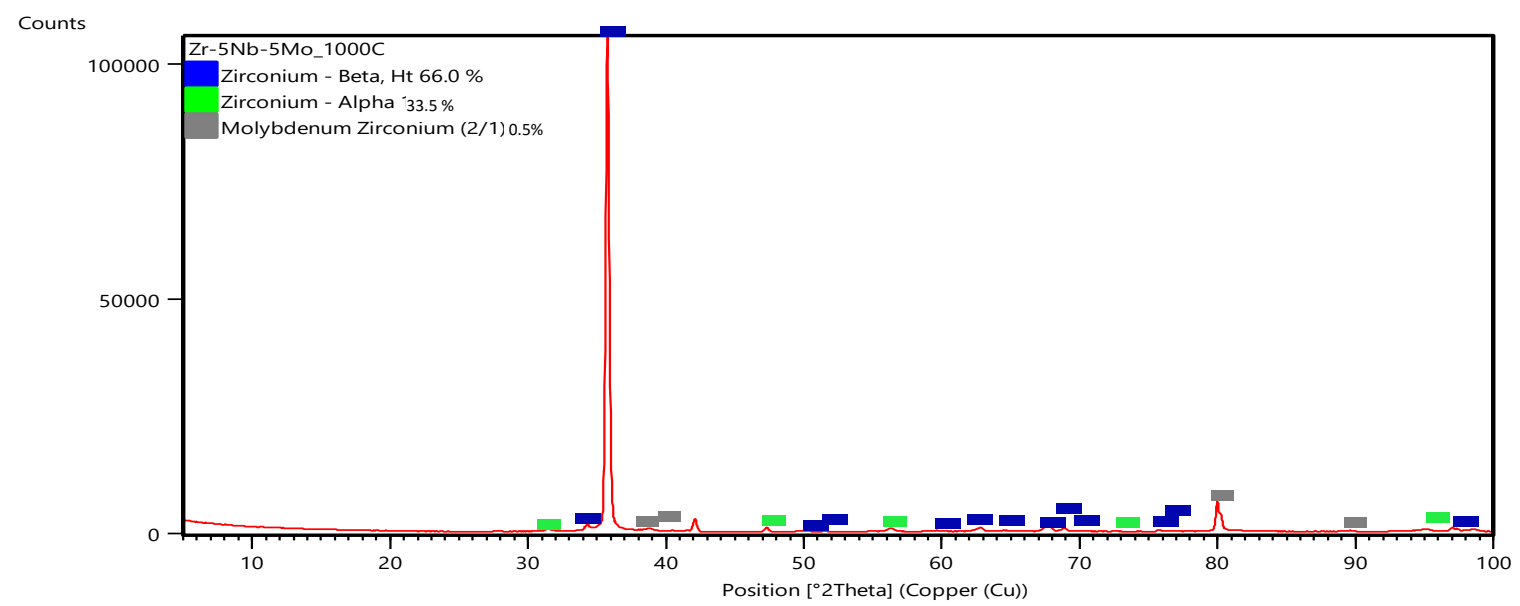

$66.0 \%$

(d)

Gambar 8.

Grafik Hasil XRD 
Paduan $\mathrm{Zr}-5 \mathrm{Nb}$ (as-cast) (a), paduan $\mathrm{Zr}$ $5 \mathrm{Nb}-1 \mathrm{Mo}$ solution treatment $900^{\circ} \mathrm{C}$ (b), paduan $\mathrm{Zr}-5 \mathrm{Nb}-5 \mathrm{Mo}$ (as-cast) (c) dan paduan $\mathrm{Zr}-5 \mathrm{Nb}-5 \mathrm{Mo}$ solution treatment $1000^{\circ} \mathrm{C}$ (d). Pada Gambar 7. grafik hasil XRD terlihat bahwa paduan biner $\mathrm{Zr}-5 \mathrm{Nb}$ dan paduan $\mathrm{Zr}-5 \mathrm{Nb}-1 \mathrm{Mo}$ memiliki fasa $\beta-\mathrm{Zr}$ dan fasa $\alpha-Z r$ tetapi untuk paduan $\mathrm{Zr}-5 \mathrm{Nb}$ $5 \mathrm{Mo}$ terdapat senyawa intermetalik Mo2Zr yang sifatnya sebagai penguat pada paduan $\mathrm{Zr}-\mathrm{Mo}^{14)}$. Semakin bertambahnya paduan Mo maka meningkatkan jumlah puncak fasa $\beta-\mathrm{Zr}$ sehingga dibuktikan bahwa Mo bersifat sebagai beta stabilizer.

\section{SIMPULAN}

Dari hasil penelitian dapat disimpulkan bahwa penambahan molibdenum dapat meningkatkan kekerasan paduan $\mathrm{Zr}-\mathrm{Nb}$ dan meingkatkan persentase fasa $\beta-Z r$, fasa $\beta-Z r$ semakin meningkat maka ketahanan korosi semakin baik, akan tetapi kekerasannya semakin turun. Pada paduan Zr-5Nb-5Mo terbentuk senyawa intermetalik $\mathrm{Mo}_{2} \mathrm{Zr}$ yang bersifat sebagai peningkat kekerasan paduan. Porses solution treatment meningkatkan persentase fasa $\beta-Z r$, tetapi fasa $\beta-Z r$ yang dihasilkan berbentuk lath martensite yang memiliki kekerasan lebih tinggi dari pada fasa $\beta-Z r$ sebelumnya, peningkatan temperatur pemanasan dapat meningkatkan persentase fasa $\beta-Z r$ dan kekerasan material, karena fasa $\alpha-Z r$ semakin halus tersebar pada butir fasa $\beta-Z r$. Sehingga material yang paling baik untuk diaplikasikan pada biomaterial adalah paduan Zr-5Nb-5Mo dengan solution treatment pada temperatur $1000^{\circ} \mathrm{C}$ karena memiliki kekerasan yang tinggi dan persentase fasa $\beta-Z r$ yang paling besar, maka ketahanan aus dan ketahanan korosi semakin meningkat dari pada paduan biner $\mathrm{Zr}-\mathrm{Nb}$.

\section{UCAPAN TERIMA KASIH}

Makalah ini merupakan hasil dari penelitian program strata satu teknik metalurgi UNJANI. Disampaikan kepada BATAN yang telah membantu penulis dalam penelitian dan ke semua pihak di UNJANI yang selalu mendukung penelitian penulis.

\section{DAFTAR PUSTAKA}

1. J.Choi and N. S. Wang, "Metals for Biomedical Applications," Biomed. Eng. - From Theory to Appl., pp. 411-430, 2011.

2. D.R. Lide, "Hardness of Minerals and Ceramics," CRC Handb. Chem. Phys., pp. 2313-2314, 2010.

3. R.R. Lima, L. M. Araujo, P. R. Affonso, K. M. Maranhão, and S. S. Lamarão, "Scanning electron microscopic investigation of dentinal tubules in Cebus apella dentin.," Ci. Anim. Bras, vol. 10, no. 4, p. 1328-1331., 2009.

4. F. Y. Zhou et al., "Microstructure, mechanical property, corrosion behavior, and in vitro biocompatibility of Zr-Mo alloys," J. Biomed. Mater. Res. - Part B Appl. Biomater., vol. 101 B, no. 2, pp. 237-246, 2013.

5. A.Yamamoto, R. Honma, and M. Sumita, "Cytotoxicity evaluation of 43 metal salts using murine fibroblasts and osteoblastic cells," J. Biomed. Mater. Res., vol. 39, no. 2, pp. 331-340, 1998.

6. D.O. Northwood, "Heat treatment, transformation reactions and mechanical properties of two high strength zirconium alloys," J. Less-Common Met., vol. 61, no. 2, pp. 199-212, 1978.

7. S.Sarker et al., "Developments in the $\mathrm{Ni}-$ $\mathrm{Nb}-\mathrm{Zr}$ amorphous alloy membranes: $A$ review," Appl. Phys. A Mater. Sci. Process., vol. 122, no. 3, 2016.

8. H. L. Yang et al., "Effect of molybdenum on microstructures in $\mathrm{Zr}-1.2 \mathrm{Nb}$ alloys after $\beta$-quenching and subsequently 873 $K$ annealing," Mater. Des., vol. 104, pp. 355-364, 2016.

9. J.S. Liang et al., "Compositional screening of Zr-Nb-Mo alloys with CALPHAD-type model for promising biomedical implants," Calphad Comput. Coupling Phase Diagrams Thermochem., vol. 56, no. December 2016, pp. 196-206, 2017.

10. H.Prajitno and Dani Gustaman, "Pembuatan Paduan Zirkaloy Dengan Teknik Pelelehan Tungku Busur Tunggal," Prosiding Pertemuan IImial Sains Materi. ISSN 1410-2897, 2010. 
11. C.Summary, G. P. Description, G. Process, F. Diagram, and $S$. Chlorination, "Thomas E . Garner , Zirconium and Hafnium Minerals ,' from Industrial Minerals and Rocks, 6th ed ., Society for Mining , Metallurgy, and Exploration, 1994, pp . 1159-1164 .U . $S$. Environmental Protection Agency, Development Document for Effluent ," vol. IX, no. May 1989, 1994.
12. W.Chubb, "High-5trength Zirconium Alloy": Zr-4 Wt Pet," no. April, pp. 461468, 1957.

13. B.Bandriyana, "Effect of $\beta$-Quenching On Oxidation Resistance Of Zirconium Alloyzrnbmoge For Fuel Cladding Material," KnE Energy, vol. 1, no. 1, pp. 1-6, 2016.

14. Suyalatu et al., "Microstructure and magnetic susceptibility of as-cast Zr-Mo alloys," Acta Biomater., vol. 6, no. 3, pp. 1033-1038, 2010. 